\title{
Regulation of placental nutrient transport and implications for fetal growth
}

\author{
Alan W. Bell* and Richard A. Ehrhardt \\ Department of Animal Science, Cornell University, Ithaca, NY 14853-4801, USA
}

\begin{abstract}
Fetal macronutrient requirements for oxidative metabolism and growth are met by placental transport of glucose, amino acids, and, to a lesser extent that varies with species, fatty acids. It is becoming possible to relate the maternal-fetal transport kinetics of these molecules in vivo to the expression and distribution of specific transporters among placental cell types and subcellular membrane fractions. This is most true for glucose transport, although apparent inconsistencies among data on the roles and relative importance of the predominant placenta glucose transporters, GLUT-1 and GLUT-3, remain to be resolved. The quantity of macronutrients transferred to the fetus from the maternal bloodstream is greatly influenced by placental metabolism, which results in net consumption of large amounts of glucose and, to a lesser extent, amino acids. The pattern of fetal nutrient supply is also altered considerably by placental conversion of glucose to lactate and, in some species, fructose, and extensive transamination of amino acids. Placental capacity for transport of glucose and amino acids increases with fetal demand as gestation advances through expansion of the exchange surface area and increased expression of specific transport molecules. In late pregnancy, transport capacity is closely related to placental size and can be modified by maternal nutrition. Preliminary evidence suggests that placental expression and function of specific transport proteins are influenced by extracellular concentrations of nutrients and endocrine factors, but, in general, the humoral regulation of placental capacity for nutrient transport is poorly understood. Consequences of normal and abnormal development of placental transport functions for fetal growth, especially during late gestation, and, possibly, for fetal programming of postnatal disorders, are discussed.
\end{abstract}

Placental transport: Glucose: Amino acids: Regulatory factors: Fetal growth

\footnotetext{
Abbreviations: GLUT, glucose transporter; IGF, insulin-like growth factor.

*Corresponding author: Professor Alan W. Bell, fax +1 607255 9829, email awb6@ cornell.edu
} 


\section{Introduction}

The placenta is an organ unique to pregnancy in higher animals, and is most highly developed in eutherian mammals. It acts as the conduit for exchange of nutrients and excreta between mother and fetus, as an endocrine regulator, as a paracrine and autocrine mediator of many pregnancy-specific physiological functions in maternal and conceptus tissues, and as an immunological 'blindfold' that serves to protect the conceptus from its maternal host. The present review will address only the nutrient transport functions of the placenta, confined to the macronutrients that support energy metabolism and synthesis of soft tissues. A major theme will be extracellular regulation of placental function and fetal growth responses as studied in vivo in the sheep and other model species. Fundamental mechanisms elucidated in studies employing isolated systems, such as placental membrane vesicles, will be discussed in the context of organismal integration. The putative endocrine roles of the placenta in regulation of maternal nutrient partitioning and fetal growth are reviewed elsewhere (Anthony et al. 1995; Bell \& Ehrhardt, 1998).

\section{Mechanisms of placental nutrient transport}

\section{Glucose and its metabolites}

Glucose. Glucose is a principal energy substrate for fetal and placental metabolism in all mammalian species studied. Analysis of the kinetics of placental glucose transport in vivo indicated that this process is achieved by facilitated diffusion (Widdas, 1952; Simmons et al. 1979). The predominant glucose transporter (GLUT) protein isoforms in the sheep placenta are GLUT-1 and GLUT-3 (Ehrhardt \& Bell, 1997; Das et al. 1998), mRNA and protein abundance of which increase with gestational age, especially for GLUT-3 (Currie et al. 1997; Ehrhardt \& Bell, 1997). The relative importance of GLUT-3 also may be inferred from its immunolocalization at the apical, maternal-facing surface of the trophoblastic cell layer that forms the fetomaternal tissue barrier in the ovine placenta (Das et al. 2000). In contrast, GLUT-1 was localized at the basolateral and apical membrane surfaces in fetal trophoblast cells. The authors suggest that this localization pattern allows a collaboration between GLUT-3 and GLUT-1 at the maternal-fetal tissue barrier in which apical GLUT-3, with a lower $K_{\mathrm{m}}$, readily takes up maternal glucose while basolateral GLUT-1, with a higher $K_{\mathrm{m}}$, facilitates its intracellular transport and exit (Das et al. 2000).

In distinct contrast, GLUT-1 is considered to be the primary GLUT in the human placenta (see Illsley, 2000). In the term placenta, at least, GLUT-1 protein was located on both the microvillous and basal membranes of the syncytiotrophoblast (Jansson et al. 1993; Barros et al. 1995), but its asymmetric distribution favoured the microvillous surface (Jansson et al. 1993; Tadokoro et al. 1996). GLUT-1 mRNA was localized predominantly in syncytial as opposed to vascular tissue (Jansson et al. 1996). Although lower abundance of GLUT-3 mRNA was distributed throughout human villous tissue (Jansson et al. 1995; Hauguel-de Mouzon et al. 1997), GLUT-3 protein was essentially absent in syncytial membranes (Jansson et al. 1993; Barros et al. 1995), and was located primarily in vascular endothelium (Hauguel-de Mouzon et al. 1997).

The different patterns of cellular and intracellular location, and inferred functional roles of GLUT-1 and GLUT-3 in human and sheep placentae cannot be explained simply in terms of species differences in placental structure. In the haemochorial rat placenta, gestational changes in relative mRNA abundance of the two isoforms (Zhou \& Bondy, 1993), and the asymmetrical 
distribution of GLUT-3 in syncytiotrophoblastic membranes (Shin et al. 1997), are much more similar to characteristics of the epitheliochorial sheep placenta than to those of the haemochorial human placenta.

In addition to the important influences of cellular configuration and kinetics of GLUT proteins in the placenta, placental glucose transfer is dependent on the maternal-fetal plasma glucose concentration gradient (Simmons et al. 1979; DiGiacomo \& Hay, 1990; Hay et al. 1990). This gradient is influenced by numerous factors that affect maternal and/or fetal glycaemia, including maternal nutrition and endocrine status, fetal growth capacity, and the variable but always large fraction of uterine glucose uptake that is consumed by the placenta (see Hay, 1995).

Lactate and fructose. Glucose taken up from the umbilical circulation is readily converted to lactate by the ovine fetal placenta in vivo (Aldoretta \& Hay, 1999). The placentae of other species, including man (Challier et al. 1986), are similarly glycolytic. Placental perfusion studies (Kastendieck et al. 1979), combined with analysis of the fetoplacental exchanges of radiolabelled glucose and lactate (Bassett, 1986), indicate that the fetomaternal interface of the ovine placenta is highly impermeable to lactate. Thus, little or none of the energetically significant net uptake of lactate by the ovine fetus is derived directly from the maternal circulation or glycolysis in the maternal caruncular tissues. In contrast, the placenta of the guinea-pig is much more permeable to lactate (Kastendieck \& Moll, 1977). The same is presumably true for other species, including man, with haemochorial placentae.

Certain species, most notably the ungulates, also metabolize fetal glucose to fructose in trophoblastic tissues nourished by the umbilical circulation (Britton et al. 1967; Meznarich et al. 1987). Like lactate, this metabolite is mostly confined within the fetoplacental compartment by the impermeability of the maternal-fetal tissue interface, consistent with the almost complete absence of fructose in the maternal circulation of species with fructogenic placentae (Goodwin, 1952). This implies that in these species, as in man (Illsley, 2000), the placenta lacks GLUT-5 or a similar protein that is responsible for fructose transport in the jejunum and some other tissues (Mueckler, 1994).

\section{Amino acids}

Most amino acids taken up by the placenta are transported against a fetal-maternal concentration gradient, implying the use of energy-dependent, active transport processes (Young \& McFadyen, 1973). Studies of isolated plasma vesicles prepared from rodent and human trophoblast have confirmed that the placenta actively transports amino acids using systems previously described for plasma membranes in other tissues (Battaglia \& Regnault, 2001). These are classified as $\mathrm{Na}$-dependent or Na-independent, and on their preference for neutral (zwitterionic), acidic (cationic), or basic (anionic) amino acids, leading to six fundamental groups: A, ASC, $\mathrm{L}$ (or $l$ ), $\mathrm{y}+, \beta$, and glycine transporter systems. Not all systems are present on the same membrane and there appears to be a greater variety of transporters on the maternal-facing microvillous membrane than on the basolateral adjacent to the umbilical microcirculation. The functional significance of these systems for transporting different categories of amino acids, including membrane location, have been comprehensively reviewed and systematically organized by Battaglia \& Regnault (2001).

Recent in vivo studies on pregnant sheep have done much to relate knowledge of aminoacid transport systems in isolated placental vesicles to the physiology of amino acid transfer 
from maternal to fetal circulations. These experiments have strongly suggested that rapid placental transport of neutral amino acids requires not only Na-dependent transport at the maternal epithelial surface, but affinity for highly reversible, Na-independent transporters located at the fetal surface (Jozwik et al. 1998). Additional studies by the same group provided supporting evidence for this hypothesis and also showed that there are major differences in placental clearance among the essential amino acids (Paolini et al. 2001). Five of the nine essential acids, namely, the branched-chain amino acids leucine, isoleucine, and valine, plus methionine and phenylalanine, have similar and relatively fast clearances, in contrast to the slower clearances of tryptophan, threonine, histidine, and lysine (Fig. 1). It is notable that the more rapidly cleared acids are all zwitterions with hydrophobic side chains. The evidence suggests that they have similar affinity for a rate-limiting transport system that mediates rapid flux from the maternal to the fetal circulation, most likely the Na-independent $\mathrm{L}$ system located on the fetal surface of the placenta (Jozwik et al. 1998). It is reassuring to note that the relative rates of in vivo transport of the amino acids studied thus far in the sheep are consistent with the more limited data for the human placenta (see Battaglia \& Regnault, 2001).

It can be inferred that many of the amino-acid transporter proteins cloned in other tissues are expressed and functional in the placenta. However, relatively few of these proteins have been cloned from placental tissue and the molecular explanation of placental amino-acid transport systems in terms of the regulated, differential expression of various transporter proteins in trophoblastic cell membranes is in its infancy (for example, Kamath et al. 1999; Ayuk et al. 2000).

\section{Fatty acids}

Placental capacity for maternal-fetal transport of short- and long-chain fatty acids and their keto-acid derivatives varies widely among species. For example, the epitheliochorial placentae of ruminants and swine generally appear to be much less permeable to fatty acids than are the

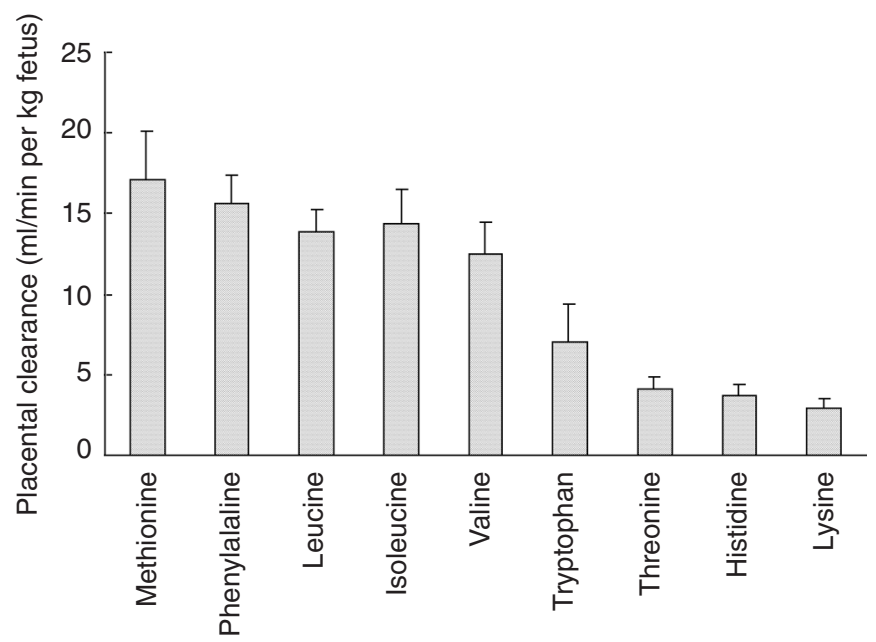

Fig. 1. Transplacental clearance of isotopically labelled essential amino acids in seven ewes during late pregnancy. Histograms are means with their standard errors shown as vertical bars. (Data are from Paolini et al. 2001.) 
haemochorial placentae of rodents, lagomorphs, and man (Battaglia \& Meschia, 1988). Thus, despite the relative abundance of acetate and other derivatives of rumen fermentation, such as 3-hydroxybutyrate, in the circulation of maternal ruminants, these substrates make only minor contributions to the energy metabolism of fetal sheep (Morriss et al. 1974; Char \& Creasy, 1976) and cattle (Comline \& Silver, 1976). Transport of long-chain, non-esterified fatty acids is similarly meagre in the sheep (Elphick et al. 1979; Leat \& Harrison, 1980) and pig (Elphick et al. 1980). However, placental transfer of non-esterified fatty acids is greater and more responsive to maternal plasma non-esterified fatty acid concentration in the rat (Hummel et al. 1975), rabbit (Elphick \& Hull, 1977), and guinea-pig (Thomas \& Lowy, 1983). Transport mechanisms have yet to be defined conclusively, but a role for a placenta-specific fatty-acid binding protein identified in man (Campbell et al. 1995) and sheep (Campbell et al. 1994) has been proposed by Dutta-Roy (2000). It also has been suggested that this protein may be involved in the preferential transfer of long-chain, polyunsaturated fatty acids from maternal plasma to the fetus (Campbell et al. 1996b). As discussed later, fetal acquisition of these vital fatty acids is additionally facilitated by placental elongation and desaturation of $\mathrm{C} 18$ essential fatty acids.

\section{Influence of placental metabolism on maternal-fetal nutrient transfer}

\section{Glucose metabolism}

Uteroplacental tissues consume $60-70 \%$ of uterine net uptake of glucose during late pregnancy in sheep and cattle (see Bell, 1993; Table 1). Placental glucose consumption is also substantial in other species, although apparently lower in the haemochorial placenta of man (Hauguel et al. 1986), rats (Leturque et al. 1987), and rabbits (Hauguel et al. 1988) than in the epitheliochorial placenta of ruminants. In sheep, uterine arterial glucose concentration determines the net uptake of glucose by the uterus from the maternal circulation, while changes in fetal arterial glucose concentration independently determine the partition of glucose between uteroplacental tissues and the fetus (Hay et al. 1990). However, under normal conditions, fetal arterial glucose concentration, and thus its influence on uteroplacental glucose consumption, is directly related to maternal arterial glucose concentration (Hay et al. 1983; Hay \& Meznarich, 1988; Leury et al. 1990a).

Table 1. Effect of maternal glucose supply on uptake and metabolism of glucose by the conceptus in eight ewes during late pregnancy* (Mean values and standard errors of the mean)

\begin{tabular}{|c|c|c|c|c|}
\hline \multirow[b]{3}{*}{ Variable } & \multicolumn{4}{|c|}{ Glucose supply† } \\
\hline & \multicolumn{2}{|c|}{ Low } & \multicolumn{2}{|c|}{ High } \\
\hline & Mean & SEM & Mean & SEM \\
\hline Maternal plasma glucose concentration (mM) & $2 \cdot 23$ & 0.13 & 4.92 & 0.29 \\
\hline Uterine glucose uptake $(\mu \mathrm{mol} / \mathrm{min})$ & 239 & 23 & 437 & 40 \\
\hline Fetal glucose uptake $(\mu \mathrm{mol} / \mathrm{min})$ & 75 & 5 & 125 & 9 \\
\hline \multicolumn{5}{|l|}{ Uteroplacental metabolic rates $(\mu \mathrm{mol} / \mathrm{min})$} \\
\hline Glucose consumption & 164 & 22 & 312 & 39 \\
\hline Lactate production & 109 & 12 & 183 & 21 \\
\hline Fructose production from glucose & 4 & 1 & 7 & 3 \\
\hline Glucose oxidation & 27 & 4 & 43 & 8 \\
\hline
\end{tabular}

* Data from Aldoretta \& Hay (1999).

† Manipulated by fasting for $24 \mathrm{~h}$ (low) and intravenous infusion of dextrose (high). 
Glucose consumed by the ovine placenta undergoes rapid conversion to lactate (about 35 $\%$ ), fructose (about $4 \%$ ), and $\mathrm{CO}_{2}$ (about $17 \%$ ), accounting for about $56 \%$ of uteroplacental glucose disposal in late-pregnant ewes with low or high maternal plasma glucose concentrations (Aldoretta \& Hay, 1999; Table 1). The metabolic fate of the remaining $44 \%$ of glucose that is apparently metabolized by the placenta is not known and requires investigation. Lactate and fructose formed in trophoblastic tissues was released into the fetal circulation while lactate formed in caruncular tissues was released into the maternal circulation, at rates that were directly related to maternal glucose supply. Rapid oxidation of glucose accounted for about 23-34\% of uteroplacental oxygen consumption, depending on maternal glycaemia (Aldoretta \& Hay, 1999). Oxidizable substrates that might contribute to the remaining 66-77\% of uteroplacental respiration include ketones (Carver \& Hay, 1995) and acetate, at least in caruncular tissues (Bell, 1993), branched-chain and certain other amino acids (see later), and C derived from the turnover of carbohydrate and lipid stores in placental tissues.

\section{Amino acid metabolism}

Placental metabolism substantially influences the quantity and composition of amino acids delivered to the fetus. Turnover of placental constitutive proteins is very rapid (Young et al. 1982) but net deposition of protein is negligible during the latter half of ovine pregnancy (Ehrhardt \& Bell, 1995). Thus, the appreciable net consumption of glutamate, serine, and branched-chain amino acids by the placenta (Liechty et al. 1991; Chung et al. 1998) implies significant catabolism or transamination of these acids. Secretion of placental peptides must account for an additional, small fraction of this net loss of amino acids.

The ovine placenta produces copious amounts of ammonia that is released into maternal and, to a much lesser extent, fetal circulations (Holzman et al. 1977; Bell et al. 1989). This is consistent with its lack of enzymic capacity for urea synthesis (Edwards et al. 1977), its extensive deamination of branched-chain amino acids to their respective keto acids, which are released into fetal and maternal circulations (Smeaton et al. 1989; Loy et al. 1990), and its rapid rate of glutamate oxidation (Moores et al. 1994). Transamination of branched-chain amino acids accounts for some of the net acquisition of glutamate by the placenta, the remainder of which is taken up from the umbilical circulation (Moores et al. 1994). That which is not quickly oxidized combines with ammonia to form glutamine, which is then released back into the fetal bloodstream (Chung et al. 1998). Some of this glutamine is converted back to glutamate in the fetal liver, which produces most of the glutamate consumed by the placenta (Vaughn et al. 1995). This glutamate-glutamine shuttle promotes placental oxidation of glutamate and fetal hepatic utilization of the amide group of glutamine.

Similarly, the placenta almost quantitatively converts serine, mostly taken up from the uterine circulation, to glycine (Chung et al. 1998), reconciling the discrepancy between the negligible net uptake of glycine by the uterus and the substantial net release of this amino acid into the umbilical circulation (Geddie et al. 1996). In addition to ensuring an adequate supply of the most abundant amino acid in fetal blood and tissues, this process is important for placental purine synthesis via donation of the side-chain $\beta$-carbon atom of serine to form methylenetetrahydrofolate.

The complex interrelationships among placental uptake, metabolism, and transport of amino acids are further illustrated by a tracer study of alanine metabolism in the late-pregnant ewe (Timmerman et al. 1998). This study revealed that the trivial net placental exchange of alanine masks an appreciable rate of metabolism of maternal alanine taken up by the placenta that 
exchanges with endogenously produced alanine. Thus, most of the alanine delivered to the fetus is of placental origin, derived from placental protein turnover and transamination.

\section{Fatty acid metabolism}

Fetal plasma and tissue lipids have characteristically low concentrations of the essential C18 fatty acids, linoleic and linolenic acids, and high concentrations of their respective C20 and C22 derivatives, arachidonic and docosahexaenoic acids, relative to the composition of maternal plasma lipids (see Noble, 1979). Although fetal tissues have some capacity to elongate and desaturate C18 acids, observed rates of maternal-fetal transfer of the these acids would provide too little substrate for fetal metabolism to account for more than a fraction of the abundance of C20 and C22 acids in fetal tissues, especially in ruminants (Elphick et al. 1979; Leat \& Harrison, 1980). Active systems for desaturation and chain-elongation of linoleic and linolenic acids have been identified in sheep placenta (Noble et al. 1985). Also, the ovine placenta has considerable capacity for hydrolysis of esterified lipids from maternal plasma that are richer than plasma non-esterified fatty acids in linoleic and linolenic acids (Clegg, 1981). Thus, placental metabolism ensures an adequate fetal supply of the longer-chain $n-6$ and $n-3$ metabolites of the $\mathrm{C} 18$ polyunsaturated fatty acids, which are the forms ultimately required by tissues.

\section{Factors affecting placental capacity for nutrient transport}

\section{Stage of gestation}

Placental capacity for glucose transport in vivo increases fivefold during the latter half of pregnancy in sheep (Molina et al. 1991). Part of this increase undoubtedly is related to placental remodelling and expansion of exchange surface area over this period (Stegeman, 1974). However, there is also a substantial gestational increase in the expression and membrane density of functional GLUT proteins as assessed by the concentration of cytochalasin B binding sites and mRNA and protein abundance of GLUT-1 and GLUT-3 (Ehrhardt \& Bell, 1997). The relative importance of GLUT-3 is indicated by its greater rate of gestational increase in protein abundance, closely correlated with an increasing fraction of cytochalasin binding that cannot be accounted for by GLUT-1, the only other GLUT of quantitative significance in the ovine placenta (Fig. 2). These results are generally consistent with gestational changes in the relative abundance of GLUT-1 and GLUT-3 in the rat placenta (Zhou \& Bondy, 1993).

In contrast, the relatively modest gestational increase in glucose transport capacity in the human placenta has been ascribed to increased expression of GLUT-1 (Sakata et al. 1995), especially in the basal membrane fraction of syncytiotrophoblastic cells (Jansson et al. 1993). Abundance of GLUT-3 mRNA in human villous tissue decreased with advancing gestation (Sakata et al. 1995).

Gestational development of placental amino-acid transport systems has not been investigated systematically in any species. However, developmental changes in expression of aminoacid transport proteins and transport kinetics have been described in rat (Novak et al. 1996) and human (Ayuk et al. 2000) placentae, and reviewed by Battaglia \& Regnault (2001). 

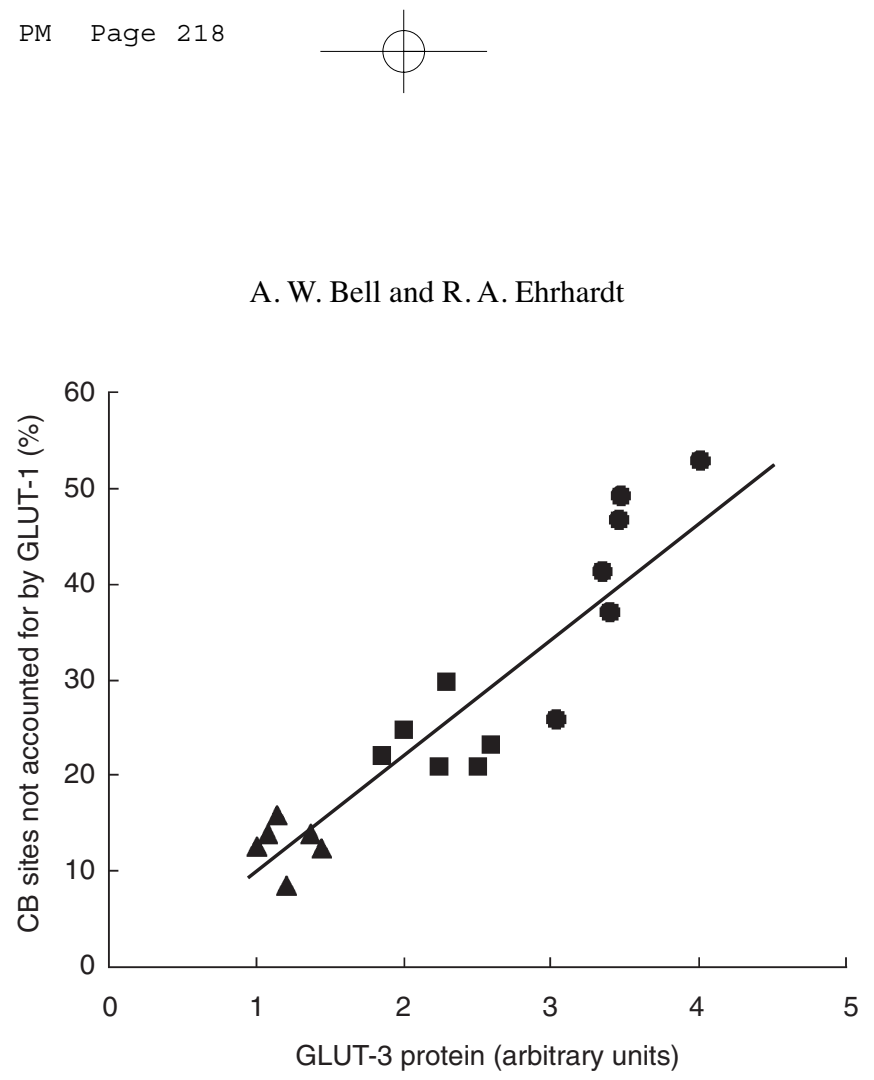

Fig. 2. Relationship $\left(R^{2} 0.86\right)$ between fraction of cytochalasin $B(C B)$ binding sites not accounted for by immunoneutralization of glucose transporter (GLUT)-1 protein and abundance of GLUT-3 protein in the placentae of ewes at $75 \mathrm{~d}(\mathbf{\Lambda}), 110 \mathrm{~d}(\boldsymbol{\square})$, and $140 \mathrm{~d}(\boldsymbol{\bullet})$ of pregnancy. Each point represents the placenta of a twin fetus. (Adapted from the data of Ehrhardt \& Bell, 1997.)

\section{Placental size and its functional correlates}

During the latter half of pregnancy, positive correlations between fetal and placental weights become progressively stronger, such that in well-nourished, polytocous ewes close to term, variation in placental weight accounts for about $90 \%$ of variation in fetal weight (Greenwood et al. 2000; Fig. 3). Various experimental manipulations have been used to demonstrate persuasively that placental weight is indeed a powerful determinant of fetal growth, especially during late gestation. These treatments include pre-mating carunclectomy, which variably reduces opportunity for establishment of cotyledonary placentation in sheep (Alexander, 1964), chronic environmental heat stress (Alexander \& Williams, 1971), and, more recently, overfeeding of relatively young, primiparous ewes (Wallace et al. 2000). Each of these procedures causes a primary reduction in placental growth that is followed by fetal growth retardation in late pregnancy (Alexander \& Williams, 1971; Vatnick et al. 1991; Robinson et al. 1995; Wallace et al. 2000). The similarity in patterns of association between fetal and placental weights caused by these approaches and that due to natural variation in polytocous ewes (Greenwood et al. 2000) suggests that they provide comparable models of placental insufficiency during late pregnancy.

Experimental and, presumably, natural reduction in placental size is highly correlated with decreases in several important determinants and indices of placental capacity for nutrient transport, and with consequent changes in fetal metabolism and growth during late gestation. For example, reduction in membrane surface area for placental exchange in carunclectomized ewes had little effect on fetal weight at $90 \mathrm{~d}$ but was insufficient for normal growth at $120 \mathrm{~d}$ of gestation (term being about 150 d) (Robinson et al. 1995). In both carunclectomized and heat-treated ewes there were also reductions in uterine and umbilical blood flows, consistent with reduced placental clearance of highly diffusible, flow-limited solutes such as antipyrine, ethanol, and ${ }^{3} \mathrm{H}_{2} \mathrm{O}$, and metabolic consequences such as reduced placental uptake and transport of oxygen, 


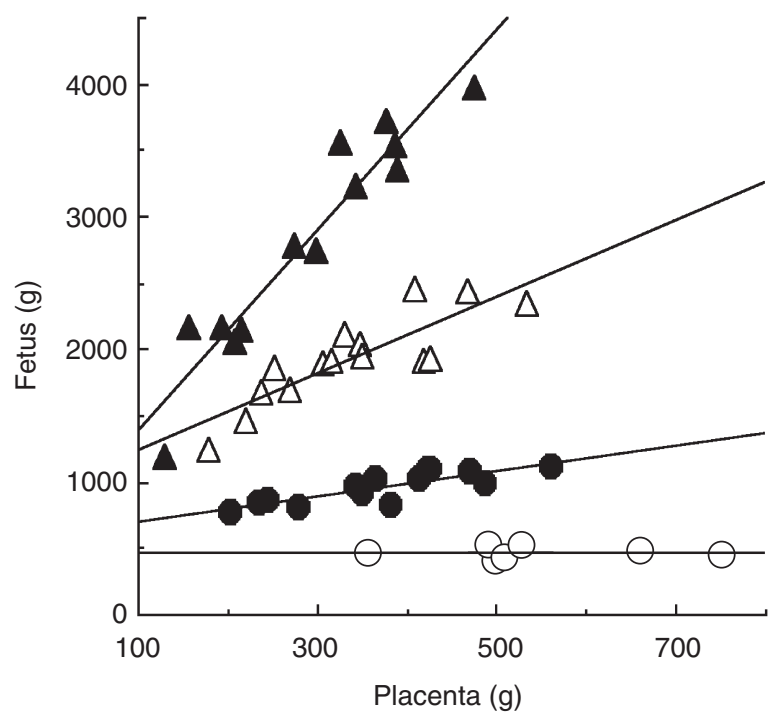

Fig. 3. Relationships between fetal weight and placental weight in ewes at $85 \mathrm{~d}\left(\bigcirc, R^{2} 0.00\right) ; 100 \mathrm{~d}\left(\boldsymbol{O}, R^{2}\right.$ $0.70) ; 115 \mathrm{~d}\left(\triangle, R^{2} 0.73\right) ; 130 \mathrm{~d}\left(\boldsymbol{\Delta}, R^{2} 0.91\right)$ of pregnancy (Greenwood et al. 2000).

and development of fetal hypoxaemia (for reviews see Bell, 1987; Owens et al. 1989; Robinson et al. 1995; Bell et al. 1999). It is unlikely that reduced placental perfusion is a primary constraint for placental transport of glucose and amino acids because the placental clearance of these nutrients is diffusion-limited rather than flow-limited. For example, the placental delivery of glucose to the umbilical circulation is not responsive to physiological variations in uterine blood flow (Wilkening et al. 1985). Severe restriction of placental perfusion, as can occur during exercise or acute heat stress (Bell, 1987), may indirectly affect active transport of amino acids through negative effects on placental energetics and ion gradients (Hay, 1998).

Placental capacity for glucose transport was reduced greatly, as were uteroplacental glucose consumption and fetal glycaemia in carunclectomized (Owens et al. 1987a,b) and heattreated (Bell et al. 1987; Thureen et al. 1992) ewes. Part of the absolute reduction in glucose transport capacity must be due to reduced exchange surface area of the trophoblastic membrane, implying fewer GLUT in total. In previously heat-treated (Thureen et al. 1992), but not in carunclectomized (Owens et al. 1987b) ewes, placental weight-specific glucose transport capacity also was reduced. Thus, chronic heat stress, which reduces average weight but not total number of placentomes, additionally reduces number and/or activity of GLUT proteins at maternal and/or fetal exchange surfaces. In contrast, carunclectomy, which reduces placentome number but may stimulate a compensatory increase in average weight of individual placentomes, caused a modest increase in placental weight-specific clearance of the nonmetabolizable glucose analogue, 3-O-methyl glucose (Owens et al. 1987b). This implies that GLUT expression was increased somewhat in the reduced number of placentomes.

Placental insufficiency in heat-treated ewes also extends to impaired capacity for amino acid transport, including major reductions in placental uptake and maternal-fetal transfer of leucine (Ross et al. 1996; Table 2) and threonine (Anderson et al. 1997). The magnitude of 
Table 2. Effect of heat-induced intra-uterine growth retardation (IUGR) on placental transfer and metabolism of leucine in thirteen ewes during late pregnancy ${ }^{\star}$ (Mean values and standard errors of the mean)

\begin{tabular}{|c|c|c|c|c|}
\hline \multirow[b]{2}{*}{ Variable } & \multicolumn{2}{|c|}{ Control } & \multicolumn{2}{|c|}{ IUGR } \\
\hline & Mean & SEM & Mean & SEM \\
\hline Fetal weight $(\mathrm{kg})$ & 3.34 & 0.14 & 1.44 & 0.11 \\
\hline Placental weight $(\mathrm{kg})$ & 0.39 & 0.03 & 0.14 & 0.02 \\
\hline \multicolumn{5}{|l|}{ Leucine fluxes ( $\mu \mathrm{mol} / \mathrm{min}$ per $\mathrm{kg}$ fetus) } \\
\hline Uterine uptake & $8 \cdot 6$ & $1 \cdot 1$ & $3 \cdot 4$ & 0.7 \\
\hline Umbilical uptake & $3 \cdot 8$ & 0.2 & 3.5 & 0.4 \\
\hline Uteroplacental oxidation & $1 \cdot 1$ & $0 . \overline{2}$ & 0.4 & $0 \cdot 1$ \\
\hline Additional uteroplacental metabolism & 3.0 & 1.2 & -0.3 & 0.6 \\
\hline \multicolumn{5}{|l|}{$\mathrm{KIC}$ fluxes ( $\mu \mathrm{mol} / \mathrm{min}$ per $\mathrm{kg}$ fetus) } \\
\hline Uterine uptake & -0.2 & 0.2 & 0.2 & 0.1 \\
\hline Umbilical uptake & 0.5 & $0 \cdot 1$ & 0.0 & 0.2 \\
\hline
\end{tabular}

$\mathrm{KIC}$, ketoisocaproic acid.

* Data from Ross et al. (1996).

these reductions implies decreased abundance and/or activity of specific transporter proteins, in addition to a reduction in exchange surface area. The normally extensive placental catabolism of leucine was also greatly reduced in heat-treated ewes (Ross et al. 1996; Table 2), presumably as a means of conserving fetal access to this essential amino acid. Fetal:maternal leucine enrichment decreased in human pregnancies exhibiting intrauterine growth retardation (Marconi et al. 1999) as in heat-treated sheep (Ross et al. 1996), suggesting similar mechanisms of transport and metabolism of leucine in the two species.

\section{Maternal nutrition}

Recent evidence from our laboratory indicates that the placenta is not merely a passive respondent to maternal nutrient supply, and that activity of placental transport mechanisms may be directly modulated by maternal nutrition. For example, moderate undernutrition of ditocous ewes for 2 weeks during late pregnancy caused a $50 \%$ increase in maternal-fetal capacity for glucose transport in vivo (Ehrhardt et al. 1996b), determined by compartmental modelling of the bi-directional exchanges of radiolabelled 3-O-methyl glucose between mother and twin fetuses (Ehrhardt et al. 1996a; Fig. 4). This was at least partly explained by a $20 \%$ increase in total GLUT abundance, assessed by binding of cytochalasin B, associated with a similar increase in GLUT-3 protein abundance (Ehrhardt et al. 1998). These responses help explain how placental glucose transfer remained sufficient to sustain normal fetal growth, despite chronic maternal hypoglycaemia and a 26 $\%$ decrease in the maternal-fetal gradient in arterial plasma glucose concentration (Bell et al. 1999).

During more severe, chronic undernutrition or starvation for several days, the development of profound fetal hypoglycaemia helps to sustain the maternal-fetal gradient in glucose concentration by restricting the reverse transfer of glucose to the placenta, and reducing placental glucose consumption (see Hay, 1995). Under these more stringent conditions, fetal gluconeogenesis is induced (Leury et al. 1990b), with amino acids being the presumed major substrate, consistent with increased fetal urea synthesis (Lemons \& Schreiner, 1983; Faichney \& White, 1987). The ultimate consequence is reduced fetal tissue protein synthesis (Krishnamurti \& Schaefer, 1984) and slowing of fetal growth to a rate that can be sustained by the reduced placental nutrient supply. 


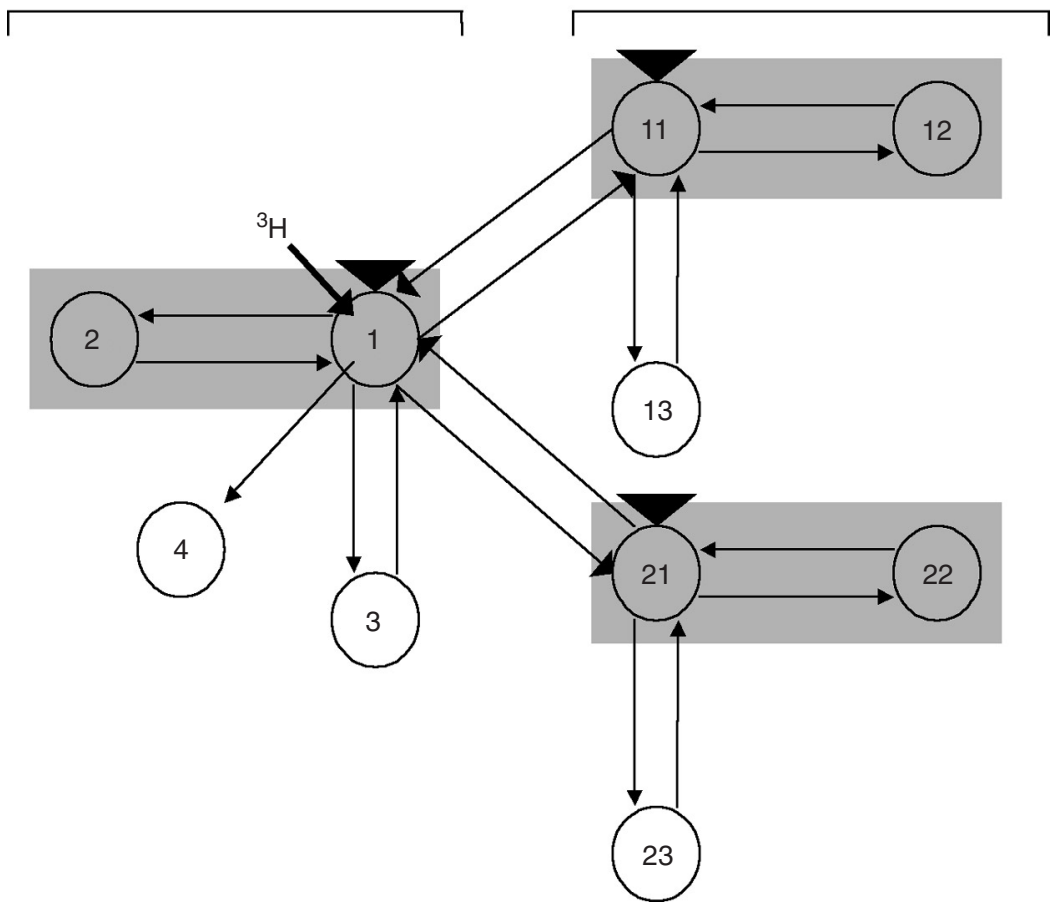

Fig. 4. Compartmental model of the kinetics of 3-O-methyl glucose (3MG) in ditocous ewes during late pregnancy, based on maternal injection of $\left[{ }^{3} \mathrm{H}\right] 3 \mathrm{MG}$. The fetal model was validated in monotocous ewes by simultaneous maternal injection of $\left[{ }^{3} \mathrm{H}\right] 3 \mathrm{MG}$ and fetal injection of $\left[{ }^{14} \mathrm{C}\right] 3 \mathrm{MG}$ (Ehrhardt et al. 1996a). (A), Blood sampling sites; $(\rightarrow)$, fractional transfer rates; $(\bigcirc)$, compartments; $(\rightarrow)$, $\left[{ }^{3} \mathrm{H}\right] 3 \mathrm{MG}$ injection site; $(0)$, extracellular distribution of 3MG. Maternal-fetal clearance of 3MG was calculated as the volume of compartment 1 cleared of tracer to compartment 11 or 21 per unit time $(\mathrm{ml} / \mathrm{min})$.

Effects of energy and/or protein supply on placental capacity for amino acid transport have been little studied. Fasting late-pregnant ewes for $5 \mathrm{~d}$ had an insignificant effect on umbilical net uptake of amino acids despite appreciable decreases in maternal arterial plasma concentrations of many amino acids (Lemons \& Schreiner, 1983). This suggests that during short-term energy-protein deprivation, placental mechanisms for active transport of amino acids are unimpaired and may even be up regulated. Under similar fasting conditions, the uteroplacental deamination of branched-chain amino acids appeared to be increased, judging from a threefold increase in the efflux of $\alpha$-ketoisocaproate, the keto-acid derivative of leucine, into uterine and umbilical circulations (Liechty et al. 1991). This suggests that increased amino acid catabolism may partly compensate for the likely reduction in placental glucose oxidation under these conditions.

Placental transport and metabolism of amino acids have not been studied during more prolonged restriction of energy or protein. However, in ewes fed adequate energy but insufficient protein during the last month of pregnancy, fetal growth and protein deposition over this period were decreased by $18 \%$ (McNeill et al. 1997). It is also relevant that in chronically hyperglycaemic ewes with secondary hyperinsulinaemia and hypoaminoacidaemia, placental and fetal uptakes of several amino acids were reduced, and fetal total $\mathrm{N}$ uptake was decreased by $60 \%$ (Thureen et al. 2001). 


\section{Extracellular regulation of placental capacity for nutrient transport}

\section{Maternal nutrient supply}

Glucose. The experimentally determined $K_{\mathrm{m}}$ for saturable glucose transport by the ovine placenta is about $3.9 \mathrm{mM}$ (Simmons et al. 1979), which is within the physiological range of glycaemia in well-fed, adult sheep. Thus, uterine uptake and placental consumption and transfer of glucose are very sensitive to arterial glucose concentration in pregnant ewes (see Hay, 1995). Emerging evidence suggests that chronic changes in maternal glycaemia may additionally modulate glucose transport capacity by influencing the placental expression of GLUT proteins. Maternal hyperglycaemia for up to 3 weeks during late pregnancy caused persistent decreases in placental concentrations of GLUT-1 (Das et al. 1998) and GLUT-3 (Das et al. 2000). In contrast, chronic, insulin-induced maternal hypoglycaemia decreased the concentration of GLUT-1 (Das et al. 1998) but had no effect on GLUT-3 (Das et al. 2000). The authors speculated that this 'relative' increase in GLUT-3 might help explain their repeated observation that placental glucose consumption was less severely affected by maternal hypoglycaemia than was placental glucose transfer to the fetus (Carver \& Hay, 1995; Das et al. 2000). It is notable that, as discussed previously, chronic hypoglycaemia in underfed, late-pregnant ewes was associated with a modest but significant increase in placental expression of GLUT-3 (Ehrhardt et al. 1998).

The possible influence of maternal glycaemia on placental expression and activity of GLUT in the human placenta is of interest, not least because of the incidence of gestational and non-gestational diabetes in women. Illsley (2000) has summarized the conflicting evidence based on culture and incubation of human trophoblastic cells over varying periods in media containing different concentrations of glucose. He concluded that while extracellular concentration of glucose may exert short-term effects on capacity for glucose transport, placental expression of GLUT-1 is refractory to changes in glucose concentrations within the physiological range. However, it remains possible that this refractoriness of the human placenta is a consequence of the in vitro conditions employed, in contrast to the relative sensitivity of the sheep placenta in vivo to physiological variations in glycaemia.

Amino acids. Relationships between maternal plasma concentration and placental transport of amino acids are complicated by the multiplicity of active transport systems, and by differing affinities of several amino acids for the same, non-specific transporters. However, it is becoming apparent that maternal concentration is an important determinant of placental transport of neutral amino acids that have a relatively high affinity for the Na-independent L exchange system located on the fetal exchange surface (Jozwik et al. 1999; Paolini et al. 2001; Thureen et al. 2001). These amino acids, which are most rapidly transported from the maternal to the fetal circulation, include the branched-chain acids, plus methionine, and phenylalanine (Paolini et al. 2001; Fig. 5). Maternal infusion has a positive effect on umbilical uptake of the branched-chain amino acids but is a relatively ineffective means of increasing fetal supply of most other amino acids (Jozwik et al. 1999).

\section{Hormones and growth factors}

Extracellular regulation of placental transport functions must be effected by direct endocrine influences, as well as by nutrient supply. The following, briefly discussed examples highlight the need for systematic investigation of this area. 


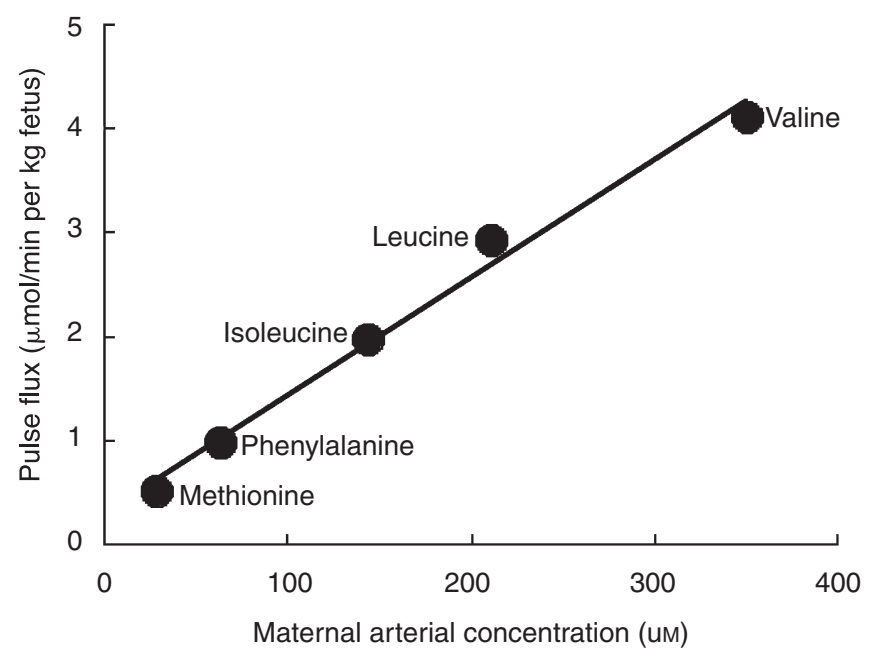

Fig. 5. Relationship ( $\left.R^{2} 0.98\right)$ between transplacental pulse flux of isotopically labelled amino acids after single injection into the maternal femoral vein and maternal plasma arterial concentration before injection for five essential amino acids that have high and similar rates of placental clearance (see p. 222 and Fig. 1). Each value is the mean of seven observations. (Adapted from the data of Paolini et al. 2001.)

Insulin. Fetal plasma insulin concentration is a regulator of glucose consumption by insulinresponsive fetal tissues (Wilkening et al. 1987). Through consequent changes in fetal glycaemia and the maternal-fetal gradient in glucose concentration, it can also influence umbilical uptake of glucose (Simmons et al. 1978). However, when respective fetal or maternal plasma glucose concentrations were controlled using the euglycaemic clamp procedure, neither fetal (Jodarski et al. 1985) nor maternal (Rankin et al. 1986) insulinaemia had any effect on the placental clearance of the non-metabolizable glucose analogue, 3-O-methyl glucose. Similarly, maternal hyperinsulinaemia had no effect on uterine or umbilical uptake of glucose when maternal euglycaemia was maintained (Hay et al. 1984). These observations are consistent with our failure to detect significant concentrations of the insulin-responsive glucose transport protein, GLUT-4, in the ovine placenta (Ehrhardt \& Bell, 1997). They also agree with the observed lack of effect of insulin on glucose uptake and transport by the human placenta (Challier et al. 1986; Brunette et al. 1990), and the failure to detect significant levels of GLUT-4 in human placental tissues (Hauguel-de Mouzon et al. 1994; Barros et al. 1995). Greater abundance of GLUT-4 has been detected in intravillous stromal cells, apparently co-localized with insulin receptors (Xing et al. 1998), but this probably has little relevance to the regulation of glucose transfer by syncytial cells.

It is also unlikely that fetal insulin indirectly promotes fetal growth via a direct influence on placental growth and functional capacity. Pancreatectomy of fetal lambs (Fowden et al. 1989) and streptozotocin treatment of fetal rabbits (Fletcher \& Bassett, 1986) profoundly reduced fetal growth without overt effects on placental development.

Insulin-like growth factors. Insulin-like growth factors (IGF)-I and -II enhanced cytochalasin B-inhibitable deoxyglucose uptake in cultured human trophoblast cells (Kniss et al. 1994). However, infusion of IGF-1 into the maternal (Liu et al. 1994) or fetal (Harding et al. 1994; Liechty et al. 1996) circulation of sheep had no effect on uterine, uteroplacental, or umbilical exchanges of glucose. These were short-term experiments and it remains possible that the IGF 
have a more chronic influence on expression and/or activity of placental GLUT. Possible local effects of IGF, their binding proteins, and other growth factors produced by the placenta also require systematic investigation.

Several lines of evidence indicate that IGF-II plays an important role in placental growth and functional development. It is abundantly expressed in various placental cell types throughout gestation (see Zumkeller, 2000) and the characteristic phenotype of mice with a null mutation of the IGF-II gene is profound placental growth retardation, associated with fetal stunting (Baker et al. 1993). This suggests an important autocrine or paracrine role for IGF-II in placental growth. In contrast, gene knockout of IGF-I had no effect on the placenta (Baker et al. 1993). Placental expression of IGF-II is paternally imprinted (DeChiara et al. 1991), offering a possible explanation for the apparently greater influence of paternal $v$. maternal genotype on prenatal growth and birth weight of cattle (Garrick et al. 1989).

Leptin. It is becoming apparent that leptin, the $o b$ gene product that is expressed principally in white adipose tissue, may have numerous peripheral functions in addition to its role as a humoral signal of energy balance to the brain (Harris, 2000). Likely target organs include the placenta, which, in sheep, strongly expresses the leptin receptor variant $\mathrm{Ob}-\mathrm{Rb}$ (Thomas et al. 2001; Ehrhardt et al. 2002) that is considered essential for intracellular signal transduction after the binding of leptin. Maternal plasma leptin concentration is elevated during early to mid pregnancy in sheep, independent of changes in body fatness (Ehrhardt et al. 2001), at a time when rapid placental growth may be most sensitive to extracellular influences (Ehrhardt \& Bell, 1995). It is, therefore, intriguing to note that elevated levels of maternal plasma leptin tended to be associated with impaired placental growth during mid gestation in overconditioned, primiparous ewes (Thomas et al. 2001). The putative role of leptin in modulation of the functional development of the placenta requires direct investigation.

\section{Implications of placental transport functions for fetal growth in late gestation}

Except under the most extreme conditions, fetal growth is little affected by maternal nutrient supply or placental capacity for nutrient transport before the last third of gestation. In late pregnancy, maternal hypoglycaemia induced by fasting or severe undernutrition of ewes is associated with a perceptible slowing of fetal growth within a few days (see Mellor, 1983). The negative influence of preceding placental growth retardation and functional insufficiency is equally clear (Bell, 1987; Robinson et al. 1995). However, there is also strong evidence that the normal and appropriate slowing of fetal growth in well-fed animals during late pregnancy is due to placental constraint (Mellor, 1983; Bell et al. 1999). The degree to which this is mediated by regulation of placental transport characteristics, independently of membrane surface area for nutrient exchange, is uncertain. For example, placental GLUT normally operate well below saturation over the range of glucose concentrations normally experienced, suggesting that their membrane concentration or activity might not be limiting for glucose transport. On the other hand, even in optimally fed, monotocous ewes with normal placentae, circumvention of the placenta by direct fetal infusion with glucose during the last month of gestation increased lamb birth weight by almost $20 \%$ (Stevens et al. 1990). The relative lack of fetal growth response to high levels of maternal protein intake (McNeill et al. 1997), consistent with the limited effect of maternal amino acid infusion on umbilical uptake of amino acids (Jozwik et al. 1999), also suggests placental limitation of the transfer of these vital nutrients. 


\section{Placental influences on fetal programming and its consequences in postnatal life}

Beginning with the observations summarized by Barker (1994), accumulating epidemiological evidence from several human populations suggests that prenatal nutrient supply affects not only patterns of growth of conceptus tissues but also the incidence of disorders such as cardiovascular disease and type II diabetes during adulthood (see Langley-Evans, 2001). This has led to the notion of 'fetal programming', based on the postulate that nutritional experience during key phases of prenatal life can indelibly alter fetal tissue development in ways that ultimately affect predisposition to systemic pathologies in later life. Altered placental function was implicated as an influencing factor through epidemiological association of increased incidence of cardiovascular disease and type II diabetes with increased placental weight:birth weight in human infants (Phillips et al. 1994; Campbell et al. 1996a; Godfrey et al. 1996). Some of these associated effects have been mimicked experimentally in animal studies, most consistently by protein undernutrition of pregnant rats (Langley \& Jackson, 1994; Langley et al. 1994; Langley-Evans et al. 1996a,b). Maternal undernutrition during early to mid pregnancy can also increase placental size in sheep without necessarily affecting later fetal growth (McCrabb et al. 1992; Heasman et al. 1998). It is not yet known if these effects on placental morphology are related to alterations in nutrient transport capacity. However, the relative enhancement of placental growth in protein-deprived, pregnant rats was associated with decreased placental activity of 11ß-hydroxysteroid dehydrogenase type 2 (Langley-Evans et al. 1996b). Resulting impairment of the placenta's ability to prevent fetal overexposure to maternal glucocorticoids has been asserted as an important determinant of fetal programming events that lead to postnatal development of hypertension and glucose intolerance in rats (Lindsay et al. 1996; Nyrienda et al. 1998) and sheep (Dodic et al. 1998; Whorwood et al. 2001).

\section{Conclusions}

The variable constraint of fetal growth by placental capacity for nutrient transport during late gestation is well documented. The functional consequences of this phenomenon range from intra-uterine growth retardation due to placental insufficiency, commonly seen in polytocous pregnancies in domestic animals, to abnormally rapid late fetal growth that can result in maternal metabolic disease, such as pregnancy toxaemia in ruminants, or dystocia and perinatal mortality. The critically important role of the placenta in optimizing fetal growth without compromising neonatal survival or maternal health is unquestioned, but the specific mechanisms are poorly understood.

Identification and molecular characterization of the proteins responsible for placental transport of glucose, amino acids, and fatty acids is under way. This will allow detailed studies of the regulation of expression and activity of these transporters by extracellular factors of maternal and fetal origin, as well as by autocrine and paracrine factors produced in the placenta itself. The insights so provided will be necessary to determine the specific nature of placental limitation of fetal nutrient supply and growth during late pregnancy. In particular, it is unclear if the limiting effects of placental capacity for nutrient transport are primarily a function of abundance or activity of nutrient transporters, distinct from the more general constraints related to the morphometry of the maternal-fetal surface for nutrient exchange. Although not discussed in the present review, it must also be recognized that the placenta plays an active role in the endocrine modulation of fetal demand and maternal supply of nutrients, as well as being a 
primary target for humoral regulatory agents. Finally, putative placental involvement in nutrition-related fetal programming of adult disease requires systematic investigation.

\section{References}

Aldoretta PW \& Hay WW Jr (1999) Effect of glucose supply on uteroplacental glucose metabolism. American Journal of Physiology 277, R947-R958.

Alexander G (1964) Studies on the placenta of the sheep (Ovis aries L.): Effect of reduction in the number of caruncles. Journal of Reproduction and Fertility 7, 307-322.

Alexander G \& Williams D (1971) Heat stress and development of the conceptus in domestic sheep. Journal of Agricultural Science, Cambridge 76, 53-72.

Anderson AH, Fennessey PV, Meschia G, Wilkening RB \& Battaglia FC (1997) Placental transport of threonine and its utilization in the normal and growth-restricted fetus. American Journal of Physiology 272, E892-E900.

Anthony RV, Pratt SL, Liang R \& Holland MD (1995) Placental-fetal hormonal interactions: impact on fetal growth. Journal of Animal Science 73, 1861-1871.

Ayuk PT, Sibley C, Donnai P, D’Souza S \& Glazier J (2000) Development and polarization of cationic amino acid transporters and regulators in the human placenta. American Journal of Physiology 278, C1162-C1171.

Baker J, Liu J-P, Robertson EJ \& Efstratiadis A (1993) Role of insulin-like growth factors in embryonic and postnatal growth. Cell 75, 73-82.

Barker DJP (1994) Mothers, Babies and Disease in Later Life. London: BMJ Publishing Group.

Barros LF, Yudilevich DL, Jarvis SM, Beaumont M \& Baldwin SA (1995) Quantitation and immunolocalization of glucose transporters in the human placenta. Placenta 16, 623-633.

Bassett JM (1986) Nutrition of the conceptus: aspects of its regulation. Proceedings of the Nutrition Society 45, 1-10.

Battaglia FC \& Meschia G (1988) Fetal nutrition. Annual Review of Nutrition 8, 43-61.

Battaglia FC \& Regnault TRH (2001) Placental transport and metabolism of amino acids. Placenta 22, 145-161.

Bell AW (1987) Consequences of severe heat stress for fetal development. In Heat Stress: Physical Exertion and Environment, pp. 313-333 [JRS Hales and DAB Richards, editors]. Amsterdam: Elsevier.

Bell AW (1993) Pregnancy and fetal metabolism. In Quantitative Aspects of Ruminant Digestion and Metabolism, pp. 405-431 [JM Forbes and J France, editors]. Oxford: CAB International.

Bell AW \& Ehrhardt RA (1998) Placental regulation of nutrient partitioning during pregnancy. In Nutrition and Reproduction, pp. 229-254 [W Hansel, GA Bray and DH Ryan, editors]. Baton Rouge: Louisiana State University Press.

Bell AW, Hay WW Jr \& Ehrhardt RA (1999) Placental transport of nutrients and its implications for fetal growth. Journal of Reproduction and Fertility 54, Suppl., 401-410.

Bell AW, Kennaugh JM, Battaglia FC \& Meschia G (1989) Uptake of amino acids and ammonia at mid-gestation by the fetal lamb. Quarterly Journal of Experimental Physiology 74, 635-643.

Bell AW, Wilkening RB \& Meschia G (1987) Some aspects of placental function in chronically heat-stressed ewes. Journal of Developmental Physiology 9, 17-29.

Britton HG, Huggett AStG \& Nixon DA (1967) Carbohydrate metabolism in the sheep placenta. Biochimica et Biophysica Acta 136, 426-440.

Brunette MG, Lajeunesse D, Leclerc M \& Lafond J (1990) Effect of insulin on D-glucose transport by human placental brush border membranes. Molecular and Cellular Endocrinology 69, 59-68.

Campbell DM, Hall MH, Barker DJ, Cross J, Shiell AW \& Godfrey KM (1996a) Diet in pregnancy and the offspring's blood pressure 40 years later. British Journal of Obstetrics and Gynaecology 103, 273-280.

Campbell FM, Gordon MJ \& Dutta-Roy AK (1994) Plasma membrane fatty acid-binding protein $\left(\mathrm{FABP}_{\mathrm{pm}}\right)$ from the sheep placenta. Biochimica et Biophysica Acta 1214, 187-192.

Campbell FM, Gordon MJ \& Dutta-Roy AK (1996b) Preferential uptake of long chain polyunsaturated fatty acids by isolated human placental membranes. Molecular and Cellular Biochemistry 155, 77-83.

Campbell FM, Taffesse S, Gordon MJ \& Dutta-Roy AK (1995) Plasma membrane fatty acid-binding protein from human placenta: identification and characterisation. Biochemistry and Biophysics Research Communications 209, 1011-1017.

Carver TD \& Hay WW Jr (1995) Uteroplacental carbon substrate metabolism and $\mathrm{O}_{2}$ consumption after long-term hypoglycemia in pregnant sheep. American Journal of Physiology 269, E299-E308.

Challier JC, Hauguel S \& Desmaizieres V (1986) Effect of insulin on glucose uptake and metabolism in the human placenta. Journal of Clinical Endocrinology and Metabolism 62, 803-807.

Char VC \& Creasy RK (1976) Acetate as a metabolic substrate in the fetal lamb. American Journal of Physiology 230, 357-361.

Chung M, Teng C, Timmerman M, Meschia G \& Battaglia FC (1998) Production and utilization of amino acids by ovine placenta in vivo. American Journal of Physiology 274, E13-E22.

Clegg RA (1981) Placental lipoprotein lipase activity in the rabbit, rat and sheep. Comparative Biochemistry and Physiology 69B, 585-591. 
Comline RS \& Silver M (1976) Some aspects of foetal and utero-placental metabolism in cows with indwelling umbilical and uterine vascular catheters. Journal of Physiology 260, 571-586.

Currie MJ, Bassett NS \& Gluckman PD (1997) Ovine glucose transporter-1 and -3: cDNA partial sequences and developmental gene expression in the placenta. Placenta 18,393-401.

Das UG, He J, Ehrhardt RA, Hay WW Jr \& Devaskar SU (2000) Time-dependent physiological regulation of the ovine placental GLUT-3 glucose transporter protein. American Journal of Physiology 279, R2252-R2261.

Das UG, Sadiq HF, Soares MJ, Hay WW Jr \& Devaskar SU (1998) Time-dependent physiological regulation of rodent and ovine placental glucose transporter (GLUT-1) protein. American Journal of Physiology 274, R339-R347.

DeChiara TM, Robertson EJ \& Efstratiadis A (1991) Parental imprinting of the mouse insulin-like growth factor II gene. Cell 64, 849-859.

DiGiacomo JE \& Hay WW Jr (1990) Placental-fetal glucose exchange and placental glucose consumption in pregnant sheep. American Journal of Physiology 258, E360-E367.

Dodic M, May N, Wintour EM \& Coghlan JP (1998) An early prenatal exposure to excess glucocorticoid leads to hypertensive offspring in sheep. Clinical Science 94, 149-155.

Dutta-Roy AK (2000) Transport mechanisms for long-chain polyunsaturated fatty acids in the human placenta. American Journal of Clinical Nutrition 71, Suppl., 315S-322S.

Edwards EM, Rattenbury JM, Varnam GC, Dhand UK, Jeacock MK \& Shepherd DAL (1977) Enzyme activities in the sheep placenta during the last three months of pregnancy. Biochimica et Biophysica Acta 497, 133-143.

Ehrhardt RA \& Bell AW (1995) Growth and metabolism of the ovine placenta during mid-gestation. Placenta 16, 727-741.

Ehrhardt RA \& Bell AW (1997) Developmental increases in glucose transporter concentration in the sheep placenta. American Journal of Physiology 273, R1132-R1141.

Ehrhardt RA, Bell AW \& Boisclair YR (1999) Analysis of leptin and leptin receptor mRNA expression in the sheep placenta. Journal of Animal Science 77, Suppl. 1, 159.

Ehrhardt RA, Bell AW \& Boisclair YR (2002) Spatial and developmental regulation of leptin in fetal sheep. American Journal of Physiology 282, R1628-R1635.

Ehrhardt RA, Boston RC, Slepetis RM \& Bell AW (1996a) Development of a compartmental model to measure maternal to fetal clearance of 3-O methyl glucose in sheep. Journal of Animal Science 74, Suppl. 1, 152.

Ehrhardt RA, Boston RC, Slepetis RM \& Bell AW (1996b) Moderate maternal undernutrition elevates placental glucose transport capacity in sheep. Journal of Animal Science 74, Suppl. 1, 152.

Ehrhardt RA, Slepetis RM \& Bell AW (1998) Moderate undernutrition alters glucose transporter levels in maternal insulin-responsive tissues and in the placenta. Journal of Animal Science 76, Suppl. 1, 130.

Ehrhardt RA, Slepetis RM, Bell AW \& Boisclair YR (2001) Maternal leptin is elevated during pregnancy in sheep. Domestic Animal Endocrinology 21, 85-96.

Elphick MC, Flecknell P, Hull D \& McFadyen IR (1980) Plasma free fatty acid umbilical venous-arterial concentration differences and placental transfer of $\left[{ }^{14} \mathrm{C}\right]$ palmitic acid in pigs. Journal of Developmental Physiology 2, 347-356.

Elphick MC \& Hull D (1977) The transfer of free fatty acids across the rabbit placenta. Journal of Physiology 264, 751-766.

Elphick MC, Hull D \& Broughton Pipkin F (1979) The transfer of fatty acids across the sheep placenta. Journal of Developmental Physiology 1, 31-45.

Faichney GJ \& White GA (1987) Effects of maternal nutritional status on fetal and placental growth and on fetal urea synthesis in sheep. Australian Journal of Biological Sciences 40, 365-377.

Fletcher JM \& Bassett JM (1986) Effects of streptozotocin injection into fetal rabbits on their subsequent growth in utero. Biology of the Neonate 49, 51-59.

Fowden AL, Hughes P \& Comline RS (1989) The effects of insulin on the growth rate of the sheep fetus during late gestation. Quarterly Journal of Experimental Physiology 74, 703-714.

Garrick DJ, Pollak EJ, Quaas RL \& Van Vleck LD (1989) Variance heterogeneity in direct and maternal weight traits by sex and percent purebred for Simmental-sired calves. Journal of Animal Science 67, 2515-2528.

Geddie G, Moores R, Meschia G, Fennessey P, Wilkening R \& Battaglia FC (1996) Comparison of leucine, serine and glycine transport across the ovine placenta. Placenta 17, 619-627.

Godfrey K, Robinson S, Barker DJP, Osmond C \& Cox V (1996) Maternal nutrition in early and late pregnancy in relation to placental and fetal growth. British Medical Journal 312, 410-414.

Goodwin RFW (1952) Fetal fructose in various mammals. Nature 170, 750.

Greenwood PL, Slepetis RM \& Bell AW (2000) Influences on fetal and placental weights during mid to late gestation in prolific ewes well nourished throughout pregnancy. Reproduction, Fertility and Development 12, 149-156.

Harding JE, Liu L, Evans PC \& Gluckman PD (1994) Insulin-like growth factor 1 alters feto-placental protein and carbohydrate metabolism in fetal sheep. Endocrinology 134, 1509-1514.

Harris RBS (2000) Leptin - much more than a satiety signal. Annual Review of Nutrition 20, 45-75.

Hauguel S, Desmaizieres V \& Challier JC (1986) Placental glucose uptake, transfer and utilization as functions of maternal glucose concentration. Pediatric Research 20, 269-273.

Hauguel S, Leturque A, Gilbert M, Kandé J \& Girard J (1988) Glucose utilization by the placenta and fetal tissues in fed and fasted pregnant rabbits. Pediatric Research 23, 480-483.

Hauguel-de Mouzon S, Challier J, Kacemi A, Caüzac M, Malek A \& Girard J (1997) The GLUT3 glucose transporter isoform is differentially expressed within human placental cell types. Journal of Clinical Endocrinology and Metabolism 82, 2689-2694. 
Hauguel-de Mouzon S, Leturque A, Alsat E, Loizeau M, Evain-Brion D \& Girard J (1994) Developmental expression of Glut1 glucose transporter and c-fos genes in human placental cells. Placenta 15, 35-46.

Hay WW Jr (1995) Regulation of placental metabolism by glucose supply. Reproduction, Fertility and Development 7 , $365-375$.

Hay WW Jr (1998) Fetal requirements and placental transfer of nitrogenous compounds. In Fetal and Neonatal Physiology, 2nd ed., pp. 619-634 [RA Polin and WW Fox, editors]. Philadelphia: Saunders.

Hay WW Jr \& Meznarich HK (1988) Effect of maternal glucose concentration on uteroplacental glucose consumption and transfer in pregnant sheep. Proceedings of the Society for Experimental Biology and Medicine 190, 63-69.

Hay WW Jr, Molina RD, DiGiacamo JE \& Meschia G (1990) Model of placental glucose consumption and transfer. American Journal of Physiology 258, R569-R577.

Hay WW Jr, Sparks JW, Gilbert M, Battaglia FC \& Meschia G (1984) Effect of insulin on glucose uptake by the maternal hindlimb and uterus, and by the fetus in conscious pregnant sheep. Journal of Endocrinology 100, 119-124.

Hay WW Jr, Sparks JW, Wilkening RB, Battaglia FC \& Meschia G (1983) Partition of maternal glucose production between conceptus and maternal tissues in sheep. American Journal of Physiology 245, E347-E350.

Heasman L, Clarke L, Firth K, Stephenson T \& Symonds ME (1998) Influence of restricted maternal nutrition in early to mid gestation on placental and fetal development at term in sheep. Pediatric Research 44, 546-551.

Holzman IR, Lemons JA, Meschia G \& Battaglia FC (1977) Ammonia production by the pregnant uterus. Proceedings of the Society for Experimental Biology and Medicine 156, 27-30.

Hummel L, Schirrmeister W \& Zimmerman T (1975) Transfer of maternal plasma free fatty acids into the rat fetus. Acta Biologica et Medica Germanica 34, 603-605.

Illsley NP (2000) Glucose transporters in the human placenta. Placenta 21, 14-22.

Jansson T, Cowley EA \& Illsley NP (1995) Cellular localization of glucose transporter messenger RNA in human placenta. Reproduction, Fertility and Development 7, 1425-1430.

Jansson T, Wennergren M \& Illsley NP (1993) Glucose transporter expression and distribution in the human placenta throughout gestation and in intrauterine growth retardation. Journal of Clinical Endocrinology and Metabolism 77, 1554-1562.

Jodarski GD, Shanahan MF \& Rankin JHG (1985) Fetal insulin and placental 3-O-methyl glucose clearance in nearterm sheep. Journal of Developmental Physiology 7, 251-258.

Jozwik M, Teng C, Battaglia FC \& Meschia G (1999) Fetal supply of amino acids and amino nitrogen after maternal infusion of amino acids in pregnant sheep. American Journal of Obstetrics and Gynecology 180, 447-453.

Jozwik M, Teng C, Timmerman M, Chung M, Meschia G \& Battaglia FC (1998) Uptake and transport by the ovine placenta of neutral nonmetabolizable amino acids with different transport system affinities. Placenta 19, 531-538.

Kamath SG, Furesz TC, Way BA \& Smith CH (1999) Identification of three cationic amino acid transporters in placental trophoblast: cloning, expression, and characterization of hCAT-1. Journal of Membrane Biology 171, 55-62.

Kastendieck E, Künzel W \& Kurz CS (1979) Placental clearance of lactate and bicarbonate in sheep. Gynecologic and Obstetric Investigation 10,9-22.

Kastendieck E \& Moll W (1977) Placental clearance of lactate and bicarbonate in the guinea pig. Pflïgers Archiv 370, $165-171$.

Kniss DA, Shubert PJ, Zimmerman PD, Landon MB \& Gabbe SG (1994) Insulinlike growth factors: their regulation of glucose and amino acid transport in placental trophoblasts isolated from first-trimester chorionic villi. Journal of Reproductive Medicine 39, 249-256.

Krishnamurti CR \& Schaefer AL (1984) Effect of acute maternal starvation on tyrosine metabolism and protein synthesis in fetal sheep. Growth 48, 391-403.

Langley SC, Browne RF \& Jackson AA (1994) Altered glucose tolerance in rats exposed to maternal low protein diets in utero. Comparative Biochemistry and Physiology 109A, 223-229.

Langley SC \& Jackson AA (1994) Increased systolic blood pressure in adult rats induced by fetal exposure to maternal low protein diet. Clinical Science 86, 217-222.

Langley-Evans SC (2001) Fetal programming of cardiovascular function through exposure to maternal undernutrition. Proceedings of the Nutrition Society 60, 505-513.

Langley-Evans SC, Gardner DS \& Jackson AA (1996a) Maternal protein restriction influences the programming of the rat hypothalamic-pituitary-adrenal axis. Journal of Nutrition 126, 1578-1585.

Langley-Evans SC, Phillips GJ, Benediktsson R, Gardner DS, Edwards CRW, Jackson AA \& Seckl JR (1996b) Protein intake in pregnancy, placental glucocorticoid metabolism and the programming of hypertension. Placenta 17, 169-172.

Leat WMF \& Harrison FA (1980) Transfer of long-chain fatty acids to the fetal and neonatal lamb. Journal of Developmental Physiology 2, 257-274.

Lemons JA \& Schreiner RL (1983) Amino acid metabolism in the ovine fetus. American Journal of Physiology 244, E459-E466.

Leturque A, Hauguel S, Kandé J \& Girard J (1987) Glucose utilization by the placenta of anaesthetized rats: effects of insulin, glucose and ketone bodies. Pediatric Research 22, 483-487.

Leury BJ, Bird AR, Chandler KD \& Bell AW (1990a) Glucose partitioning in the pregnant ewe: effects of undernutrition and exercise. British Journal of Nutrition 64, 449-462.

Leury BJ, Bird AR, Chandler KD \& Bell AW (1990b) Effects of maternal undernutrition and exercise on glucose kinetics in fetal sheep. British Journal of Nutrition 64, 463-472. 
Liechty EA, Boyle DW, Moorehead H, Lee W-H, Bowsher RR \& Denne SC (1996) Effects of circulating IGF-1 on glucose and amino acid kinetics in the ovine fetus. American Journal of Physiology 271, E177-E185.

Liechty EA, Kelley J \& Lemons JA (1991) Effect of fasting on uteroplacental amino acid metabolism in the pregnant sheep. Biology of the Neonate 60, 207-214.

Lindsay RS, Lindsay RM, Edwards CRW \& Seckl JR (1996) Inhibition of 11ß-hydroxysteroid dehydrogenase in pregnant rats and the programming of blood pressure in offspring. Hypertension 27, 1200-1204.

Liu L, Harding JE, Evans PC \& Gluckman PD (1994) Maternal insulin-like growth factor-1 infusion alters feto-placental carbohydrate and protein metabolism in pregnant sheep. Endocrinology 135, 895-900.

Loy GL, Quick AN Jr, Hay WW Jr, Meschia G, Battaglia FC \& Fennessey PV (1990) Fetoplacental deamination and decarboxylation of leucine. American Journal of Physiology 259, E492-E497.

McCrabb GJ, Egan AR \& Hosking BJ (1992) Maternal undernutrition during mid-pregnancy in sheep: variable effects on placental growth. Journal of Agricultural Science, Cambridge 118, 127-132.

McNeill DM, Slepetis R, Ehrhardt RA, Smith DM \& Bell AW (1997) Protein requirements of sheep in late pregnancy: partitioning of nitrogen between gravid uterus and maternal tissues. Journal of Animal Science 75, 809-816.

Marconi AM, Paolini CL, Stramare L, Cetin I, Fennessey PV, Pardi G \& Battaglia FC (1999) Steady state maternal-fetal leucine enrichments in normal and intrauterine growth-restricted pregnancies. Pediatric Research 46, 114-119.

Mellor DJ (1983) Nutritional and placental determinants of foetal growth rate in sheep and consequences for the newborn lamb. British Veterinary Journal 139, 307-324.

Meznarich HK, Hay WW Jr, Sparks JW, Meschia G \& Battaglia FC (1987) Fructose disposal and oxidation rates in the ovine fetus. Quarterly Journal of Experimental Physiology 72, 617-625.

Molina RD, Meschia G, Battaglia FC \& Hay WW Jr (1991) Gestational maturation of placental glucose transfer capacity in sheep. American Journal of Physiology 261, R697-R704.

Moores RR Jr, Vaughn PR, Battaglia FC, Fennessey PV, Wilkening RB \& Meschia G (1994) Glutamate metabolism in the fetus and placenta of late-gestation sheep. American Journal of Physiology 267, R89-R96.

Morriss FH, Boyd RD, Makowski EL, Meschia G \& Battaglia FC (1974) Umbilical V-A differences of acetoacetate and $\beta$-hydroxybutyrate in fed and starved ewes. Proceedings of the Society for Experimental Biology and Medicine 145, 879-883.

Mueckler M (1994) Facilitative glucose transporters. European Journal of Biochemistry 219, 713-725.

Noble RC (1979) Lipid metabolism in the neonatal ruminant. Progress in Lipid Research 18, 179-216.

Noble RC, Shand JH \& Christie WW (1985) Synthesis of C20 and C22 polyunsaturated fatty acids by the placenta of the sheep. Biology of the Neonate 47, 333-338.

Novak DA, Beveridge MJ, Malandro M \& Seo J (1996) Ontogeny of amino acid transport system A in rat placenta. Placenta 17, 643-651.

Nyrienda MJ, Lindsay RS, Kenyon CJ, Burchell A \& Seckl JR (1998) Glucocorticoid exposure in late gestation permanently programs rat hepatic phosphoenolpyruvate carboxykinase and glucocorticoid receptor expression and causes glucose intolerance in adult offspring. Journal of Clinical Investigation 101, 2174-2181.

Owens JA, Falconer J \& Robinson JS (1987a) Effect of restriction of placental growth on fetal and utero-placental metabolism. Journal of Developmental Physiology 9, 225-238.

Owens JA, Falconer J \& Robinson JS (1987b) Restriction of placental size in sheep enhances efficiency of placental transfer of antipyrine, 3-O-methyl-D-glucose but not urea. Journal of Developmental Physiology 9, 457-464.

Owens JA, Owens PC \& Robinson JS (1989) Experimental growth retardation: metabolic and endocrine consequences. In Research in Perinatal Medicine VIII. Advances in Fetal Physiology, pp. 263-286 [PD Gluckman, BM Johnston and PW Nathanielsz, editors]. Ithaca: Perinatology Press.

Paolini CL, Meschia G, Fennessey PV, Pike AW, Teng C, Battaglia FC \& Wilkening RB (2001) An in vivo study of ovine placental transport of essential amino acids. American Journal of Physiology 280, E31-E39.

Phillips DIW, Barker DJP, Hales CN, Hirst S \& Osmond C (1994) Thinness at birth and insulin resistance in adult life. Diabetologia 37, 150-154.

Rankin JHG, Jodarski G \& Shanahan MR (1986) Maternal insulin and placental 3-O-methyl glucose transport. Journal of Developmental Physiology 8, 247-253.

Robinson J, Chidzanja S, Kind K, Lok F, Owens P \& Owens J (1995) Placental control of fetal growth. Reproduction, Fertility and Development 7, 333-344.

Ross JC, Fennessey PV, Wilkening RB, Battaglia FC \& Meschia G (1996) Placental transport and fetal utilization of leucine in a model of fetal growth retardation. American Journal of Physiology 270, E491-E503.

Sakata M, Kurachi H, Imai T, Tadokoro C, Yamaguchi M, Yoshimoto Y, Oka Y \& Miyake A (1995) Increase in human placental glucose transporter-1 during pregnancy. European Journal of Endocrinology 132, 206-212.

Shin B-C, Fujikura K, Suzuki T, Tanaka S \& Takata K (1997) Glucose transporter GLUT3 in the rat placental barrier: a possible machinery for the transplacental transfer of glucose. Endocrinology 138, 3997-4004.

Simmons MA, Battaglia FC \& Meschia G (1979) Placental transfer of glucose. Journal of Developmental Physiology 1, 227-243.

Simmons MA, Jones MD Jr, Battaglia FC \& Meschia G (1978) Insulin effect on fetal glucose utilization. Pediatric Research 12, 90-92.

Smeaton TC, Owens JA, Kind KL \& Robinson JS (1989) The placenta releases branched-chain amino acids into the umbilical and uterine circulations in the pregnant sheep. Journal of Developmental Physiology 12, 95-99. 
Stegeman JHG (1974) Placental development in the sheep and its relation to fetal development. Bijdragen tot de Dierkunde 44, 1-72.

Stevens D, Alexander G \& Bell AW (1990) Effect of prolonged glucose infusion into fetal sheep on body growth, fat deposition and gestation length. Journal of Developmental Physiology 13, 277-281.

Tadokoro C, Yoshimoto Y, Sakata M, Fujimiya M, Kurachi H, Adachi E, Maeda T \& Miyake A (1996) Localization of human placental glucose transporter 1 during pregnancy. An immunohistochemical study. Histology and Histopathology 11, 673-681.

Thomas CR \& Lowy C (1983) Placental transfer of free fatty acids: factors affecting transfer across the guinea-pig placenta. Journal of Developmental Physiology 5, 323-332.

Thomas L, Wallace JM, Aitken RP, Mercer JG \& Trayhurn P (2001) Circulating leptin during ovine pregnancy in relation to maternal nutrition, body composition and pregnancy outcome. Journal of Endocrinology 169, 465-476.

Thureen P, Trembler KA, Meschia G, Makowski EL \& Wilkening RB (1992) Placental glucose transport in heatinduced fetal growth retardation. American Journal of Physiology 263, R578-R585.

Thureen, PJ, Padbury JF \& Hay WW Jr (2001) The effect of maternal hypoaminoacidaemia on placental uptake and transport of amino acids in pregnant sheep. Placenta 22, 162-170.

Timmerman M, Chung M, Wilkening RB, Fennessey PV, Battaglia FC \& Meschia G (1998) Relationship of fetal alanine uptake and placental alanine metabolism to maternal alanine concentration. American Journal of Physiology 275, E942-E950.

Vatnick I, Ignotz G, McBride BW \& Bell AW (1991) Effect of heat stress on ovine placental growth in early pregnancy. Journal of Developmental Physiology 16, 163-166.

Vaughn PR, Lobo C, Battaglia FC, Fennessey PV, Wilkening RB \& Meschia G (1995) Glutamine-glutamate exchange between placenta and fetal liver. American Journal of Physiology 268, E705-E711.

Wallace JM, Bourke DA, Aitken RP, Palmer RM, Da Silva P \& Cruickshank MA (2000) Relationship between nutritionally-mediated placental growth restriction and fetal growth, body composition and endocrine status during late gestation in adolescent sheep. Placenta 21, 100-108.

Whorwood CB, Firth KM, Budge H \& Symonds ME (2001) Maternal undernutrition during early to midgestation programs tissue-specific alterations in the expression of the glucocorticoid receptor, $11 \beta$-hydroxysteroid dehydrogenase isoforms, and type 1 angiotensin II receptor in neonatal sheep. Endocrinology 142, 2854-2864.

Widdas WF (1952) Inability of diffusion to account for placental glucose transfer in the sheep and consideration of the kinetics of a possible carrier transfer. Journal of Physiology 118, 23-39.

Wilkening RB, Battaglia FC \& Meschia G (1985) The relationship of umbilical glucose uptake to uterine blood flow. Journal of Developmental Physiology 7, 313-319.

Wilkening RB, Molina RD, Battaglia FC \& Meschia G (1987) Effect of insulin on glucose/oxygen and lactate/oxygen quotients across the hindlimb of fetal lambs. Biology of the Neonate 51, 18-23.

Xing AY, Challier JC, Leperq L, Caüzac M, Charron MJ, Girard J \& Hauguel-de Mouzon S (1998) Unexpected expression of glucose transporter 4 in villous stromal cells of human placenta. Journal of Clinical Endocrinology and Metabolism 83, 4097-4101.

Young M \& McFadyen IR (1973) Placental tranfer and fetal uptake of amino acids in the pregnant ewe. Journal of Perinatal Medicine 1, 174-182.

Young M, Stern MDR, Horne J \& Noakes DE (1982) Protein synthetic rate in the sheep placenta in vivo: the influence of insulin. Placenta 3, 159-164.

Zhou J \& Bondy CA (1993) Placental glucose transporter gene expression and metabolism in the rat. Journal of Clinical Investigation 91, 845-852.

Zumkeller W (2000) The role of growth hormone and insulin-like growth factors for placental growth and development. Placenta 21, 451-467. 